\title{
Artur WIERZBICKI
}

Uniwersytet im. Adama Mickiewicza, Poznań

\section{Wizerunek samorządu terytorialnego w prasie lokalnej}

Do przeszło dziesięciu latach od powołania samorządu terytorialnego w Polsce, stał się on już nierozerwalnym elementem życia społecznego. Władza samorządowa, wywodząca się ze środowiska lokalnego i na nie bezpośrednio wpływająca, równie szybko stała się dla prasy wydawanej w poszczególnych gminach (i później w powiatach) tematem interesującym i ważnym ${ }^{1}$. Ponadto, zależności pomiędzy prasą lokalną a organami samorządu, zwłaszcza te o charakterze personalnym, pozostają do dzisiaj znacznie silniejsze niż w przypadku mediów o charakterze regionalnym i ogólnopolskim. Często to one właśnie miały główny wpływ na charakter danego pisma ${ }^{2}$.

Nie ulega wątpliwości, że sposób prezentacji tematyki samorządowej oraz charakter jej ekspozycji wpływa na postawy odbiorców pisma wobec lokalnej władzy. Uzasadnione staje się więc pytanie o wizerunek samorządu lokalnego, jaki pojawia się w polskiej prasie lokalnej (powiatowej), zwłaszcza tam, gdzie istnieje (i utrzymuje się) kilka tytułów.

Dla potrzeb pracy zostały wybrane i poddane analizie dwa tygodniki rozprowadzane na obszarze całego powiatu wągrowieckiego, dominujące pod względem nakładu ${ }^{3}$ :

- „Głos Wagrowiecki” (GW) - czasopismo o największym nakładzie, 7000 egzemplarzy, wydawane przez Wagrowiecką Oficynę Wydawniczą.

- „Tygodnik Wagrowiecki” (TW) - posiadający nakład 4000 egzemplarzy. Jest on sublokalnym wydaniem „Gazety Poznańskiej”, posiadającym jednak własną redakcję i współpracowników.

Próba, na podstawie której dokonano analizy, obejmowała w tym przypadku wszystkie numery od lipca 2002 do czerwca 2003. Jako podstawę

Zob. S. Dziki, W. Chorąki, Media lokalne i regionalne, w: Dziennikarstwo $i$ świat mediów, red. Z. Bauer, E. Chudziński, Kraków 2000, s. 121-140.

2 O zależnościach pomiędzy władzą samorządową i prasą lokalną oraz ich wzajemnym wpływie zob. Andrzej K. Piasecki, Samorzqd terytorialny a media lokalne (1990-2002) - próba syntezy, ,Zeszyty Prasoznawcze” 2003, nr 1-2, s. 141-155.

3 Dane dotyczące nakładu wg Katalogu Mediów Polskich, http://media.onet.pl (10.01.04). 
podziału treści zastosowano klucz kategoryzacyjny stworzony na potrzeby analiz mediów lokalnych zawartych w pracy R. Kowalczyka ${ }^{4}$, który do kategorii „samorząd terytorialny” (obejmujący gminy, powiaty i województwa) zalicza następujące elementy: 1) organy samorządu terytorialnego, 2) ochrona środowiska, 3) ochrona zdrowia, 4) pomoc i opieka społeczna, 5) gospodarka komunalna i mieszkaniowa, 6) współpraca z zagranica, 7) straż pożarna, 8) straż miejska ${ }^{5}$, 9) problematyka wiejska, 10) samorząd sołecki i osiedlowy ${ }^{6}$.

\section{Organy samorządu terytorialnego}

$\mathrm{W}$ tej kategorii dominują relacje $\mathrm{z}$ obrad rad miejskich (gminnych) i powiatowych. Najbardziej rozbudowane są relacje z obrad Rady Miejskiej w Wagrowcu. Przybierają one często charakter stenograficzny, przytaczane są wypowiedzi poszczególnych mówców i reakcje pozostałych radnych na ich słowa. Relacje z obrad rady wiejskiej gminy Wagrowiec oraz pozostałych gmin powiatu wagrowieckiego są zwykle krótsze i ograniczają się do podawania najważniejszych punktów obrad i uchwalonych zarządzeń i wniosków. Rozbudowaną formę, przypominającą tę z obrad rady miejskiej stolicy powiatu, przybierają one, gdy podczas obrad uchwalane są rzeczy istotne z punktu widzenia społeczności lokalnej, jak choćby likwidacja przedsiębiorstw komunalnych, prowadząca do zwolnień czy opóźnienia w wypłatach dodatków motywacyjnych dla nauczycieli. Emocje i kategoryczność sądów wyrażane są wtedy już zwykle w tytułach (Skoki - Radni zdecydowali: już po ,,komunalce” [tytuł] GW 07.02.03; Gmina Wagrowiec - Gmina musi zapłacić nauczycielom [tytuł] TW 17.01.03).

Często daje się odczuć krytyczny i ironiczny stosunek czasopism do radnych. Dominuje on zwłaszcza, gdy relacje dotyczą obrad Rady Miasta w Wagrowcu (,Bez jakichkolwiek niespodzianek przebiegała ubiegłowtorkowa sesja Rady Miejskiej. Koalicja Sojuszu Lewicy Demokratycznej Unii Pracy - Samorządności Wagrowieckiej 2000 rozdzieliła między

4 R. Kowalczyk, Prasa lokalna w systemie komunikowania społecznego, Poznań 2002.

5 W analizowanych numerach obydwu czasopism nie stwierdzono artykułów odnoszących się do funkcjonowania straży miejskiej.

6 Wykorzystywany tu klucz kategoryzacyjny jest jednym z najnowszych (z 2002 r.). Ze względu na charakter pracy nie zachodziła potrzeba utworzenia nowego klucza. 
siebie wszystkie stanowiska w miejskim parlamencie” GW 29.11.02; „Gwoździem programu tej sesji miało być udzielenie absolutorium wagrowieckiemu burmistrzowi, Stanisławowi Wilczyńskiemu" GW 02.05.03). Jednak również i w relacjach z obrad z okolicznych gmin, chociaż znacznie rzadziej, pobrzmiewa negatywne nastawienie autorów do prac rad gminnych, jak i samych radnych, co manifestuje się użyciem słownictwa wyraźnie nacechowanego aksjologicznie (Rogoźno - „Radni wyraźnie chcieli się zabezpieczyć przed poruszaniem tej sprawy przez media, próbując oczarować Barbarę Budziszewską Sas zapewnieniami, iż uda się tą sprawę jakoś rozwiązać. Zabiegi burmistrza Czesława Gruszki i przewodniczącego rady Zdzisława Hinza były tak skuteczne, że kobieta postanowiła wstrzymać się z nadaniem tej sprawy rozgłosu w mediach [...]" TW 11.10.02; Blaski i cienie samorzqdu w Mieścisku [tytuł], Afery i tajemnice, czyli co się działo w Mieścisku [podtytuł] TW 20.09.02). Podobnym celom, mającym ponadto uwiarygodnić negatywny stosunek autora do rady, służy odpowiedni dobór wypowiedzi radnych (Skoki - ,-To wszystko prawda, że jesteście fałszywi - powiedział o innych radnych Leszek Gronowicz z Rejowca" GW 06.06.03).

Nieco inaczej przedstawiani są burmistrzowie i wójtowie. Najczęściej i najobszerniej prezentowana jest działalność burmistrza Wagrowca ${ }^{7}$. Różnica w stosunku do relacji z posiedzeń rad polega jednak na tym, że burmistrz w artykułach głównych zwykle przedstawiany jest pozytywnie lub w sposób obojętny, negatywnie natomiast w komentarzach, często nawet odnoszących się do tego samego artykułu. Taka sytuacja pojawia się zwłaszcza wtedy, gdy w grę wchodzą także interesy czasopisma („Delegacja samorządowa zabrała ze sobą jedynie przedstawiciela Wagrowieckiej Telewizji Kablowej, «zapominając» o pozostałych mediach. Widać wyraźnie, że - zdaniem burmistrza i jego świty - dziennikarze bywają równi, a nawet równiejsi..." GW 25.04.03).

Cechą charakterystyczną natomiast dla "Głosu Wagrowieckiego” jest przedstawianie burmistrza Wagrowca na zdjęciach w sytuacjach nie związanych z jego funkcją samorządową. Wówczas obecność burmistrza ma, prawdopodobnie w zamierzeniu autorów, stanowić nobilitację wydarzenia i podniesienie jego rangi (,Do protestujących dzieci przyłączył się burmistrz Stanisław Wilczyński” [komentarz pod zdjęciem] GW 06.12.02;

Podobnie jak w przypadku relacji z obrad wagrowieckiej Rady Miejskiej, ma to związek z tym, że miasto Wagrowiec jest prawdopodobnie największym odbiorcą obu czasopism. 
„Burmistrz Wagrowca z zainteresowaniem oglądał profilaktyczną literaturę" [komentarz pod zdjęciem] GW 21.03.03). Niestety, taki sposób prezentacji może jednak osłabiać jego charakter nobilitujący ${ }^{8}$. W podobny sposób, ale nieporównanie rzadziej, na łamach tego czasopisma przedstawiani są pozostali burmistrzowie i wójtowie gmin powiatu wagrowieckiego.

Wizerunek władzy powiatowej na łamach obu czasopism ogranicza się zwykle do przedstawiania relacji z posiedzeń Rady Powiatu. W „Głosie Wagrowieckim" sposób prezentacji jest podobny do tego w jaki relacjonowano sesje Rady Miejskiej w Wagrowcu - przypominają one sprawozdania, wypowiedzi i wystapienia radnych przedstawiane są w porządku chronologicznym. Wybór ich wydaje się jednak być tendencyjny, w wyniku tego zaznacza się negatywny stosunek autorów tekstów do tego organu władzy (,-Poszli kupczyć! - skomentował to jeden z lewicowych radnych" GW 06.06.03). Podobny, ale znacznie wyraźniejszy negatywny ton pojawia się w komentarzach redakcyjnych („Sesja powiatowego parlamentu jest miejscem, gdzie powinno się załatwiać sprawy dotyczące całej wspólnoty powiatowej, a nie kilku osób. [...] - Jestem za wolną prasą-powiedziała radna T. Walewska. A ja jestem za tym, żeby radni zajęli się ... pracą, a nie publicznymi polemikami w sprawach, które dotyczą głównie ich samych” GW 07.02.03; „Inwestycyjnych potrzeb w powiecie jest bez liku, ale trzeba ustalić priorytety pod kątem społecznie i ekonomicznie uzasadnionych potrzeb wszystkich mieszkańców powiatu, a nie tylko jednego środowiska czy widzimisie politycznego ugrupowania" [podkr. red.] GW 06.06.03). Taki nacechowany emocjonalnie sposób prezentacji dominuje zwłaszcza w „Głosie Wagrowieckim”. ,Tygodnik Wagrowiecki" natomiast ogranicza się do krótkich notatek przedstawiających główne problemy poruszane na zakończonych obradach.

W obydwu czasopismach brak jest tematów związanych z funkcjonowaniem samorządu wojewódzkiego. Ma to prawdopodobnie związek z deklaracjami tygodników jako pisma powiatowe, poza tym treści dotyczące samorządu wojewódzkiego pojawiały się w dodawanych do nich

8 Temu swoistemu użyciu retorycznego argumentu ad verecundiam nie służy szablonowość i powielanie w podpisie treści obrazu. Por. „Powtarzanie treści uprzednio dobrze znanych czytelnikowi albo dających się łatwo wyczytać ze zdjęcia nie tylko nie wzbogaca praktycznej wartości informacyjnej wypowiedzi, ale - co gorsza - zmniejsza jej atrakcyjność i utrudnia znalezienie rzeczywistej informacji w gąszczu wyrazów całkowicie jej pozbawionych". W. Pisarek, Nowa retoryka dziennikarska, Kraków 2002, s. 261. 
dziennikach regionalnych, „Głosie Wielkopolskim” („Głos Wagrowiecki”) i „Gazecie Poznańskiej” („Tygodnik Wagrowiecki”).

\section{Ochrona środowiska}

Problematyka ochrony środowiska nie jest zbyt często przedstawiana na łamach obydwu czasopism, w odróżnieniu od tematyki ekologicznej zaliczanej jednak przez wykorzystywany klucz do kategorii „Przyroda ożywiona i nieożywiona”. Zagadnienia związane z ochroną środowiska (jako jednym z zadań samorządu lokalnego) koncentrują się więc w omawianej kategorii na inwestycjach poprawiających stan środowiska, których inwestorem jest samorząd. Są nimi głównie modernizacje systemów kanalizacyjnych i budowy oczyszczalni ścieków (Rogoźno - Co dalej z kanalizacja? [tytuł] TW 20.09.02). Omawiane tygodniki zauważają także poparcie samorządów dla inicjatyw oddolnych poprawiających stan środowiska oraz uczestnictwo samorządowców w szkoleniach z zakresu ochrony środowiska (Rady na odpady [tytu1] GW 21.03.03).

Powyższe zagadnienia związane z problematyką ochrony środowiska zwykle mają postać krótkich artykułów lub tylko notatek. Brak jest tu słownictwa, wyrażeń i zwrotów nacechowanych jednoznacznie oraz sądów autorów tekstów do omawianych problemów.

\section{Ochrona zdrowia}

Jednym z zadań samorządu powiatowego jest zapewnienie mieszkańcom ochrony zdrowia. Artykuły dotyczące tej kategorii koncentrują się na działalności szpitala powiatowego w Wagrowcu. Pojawiają się zwykle jako relacje z posiedzeń Rady Społecznej przy tutejszym Zespole Opieki Zdrowotnej, której częściąjest szpital. Zauważane przez lokalnych dziennikarzy są także nowe nabytki szpitala i dary pochodzące od Wielkiej Orkiestry Świątecznej Pomocy oraz zmiany poprawiające standard świadczonych usług, jak choćby zmiana wystroju oddziału dziecięcego szpitala na bardziej kolorowy i przyjazny dla małych pacjentów. W centrum uwagi obydwu tygodników pozostają kwestie finansowe, zwłaszcza wysokość kontraktów. Jednak, poza kłopotami finansowymi, podkreślane są także pozytywne dokonania dyrekcji zmierzające do poprawy ekonomicznej sytuacji szpitala. (,W minionym kwartale na inwestycje przezna- 
czono prawie 40 tys. zł. [...] Sukcesywnie zmniejsza się też zadłużenie powiatowej lecznicy: o ile pod koniec lutego wynosiło ono $415804 \mathrm{zł}$, to miesiąc później spadło do 164386 zł.” GW 25.04.03; „W tym roku wagrowiecki szpital będzie miał straty sięgające ćwierć miliona złotych. [...] Mimo kłopotów finansowych, dyrekcji szpitala udało się wywalczyć nowy laparoskop dla oddziału chirurgii” TW 27.06.03). Różnice między czasopismami w sposobie relacjonowania ujawniają się jednak, gdy przedmiotem uwagi dziennikarzy staje się wysokość wynagrodzenia dyrektora szpitala. W artykule „Tygodnika Wagrowieckiego” dominuja słowa i wyrażenia nacechowane emocjonalnie, mające wśród czytelników wzbudzić negatywne postawy (Dajcie mu podwyżkę, bo ma mało! [tytuł]; „Na ostatnim posiedzeniu Rady Społecznej ZOZ biegła rewident, która sprawdzała stan finansów wagrowieckiego szpitala, nieoczekiwanie uznała, że ... dyrektor zasłużył na podwyżkę”; „Dyrektor zarabia 6000 zł brutto. Czy to mało?" [podpis pod zdjęciem] TW 23.05.03). Natomiast „Głos Wagrowiecki” relacjonując ten sam fakt ogranicza się tylko do zacytowania wypowiedzi biegłej rewident podczas posiedzenia Rady Społecznej. Brak jest tu komentarza redakcyjnego, a zastosowanie cytatu może nawet nasuwać u czytelników pozytywne skojarzenia co do pracy dyrektora („,Dyrekcja jest bardzo zaangażowana w pozyskiwanie środków. Niestety, wynagrodzenie dyrektora jest nieadekwatne do wykonywanej pracy. Jak zdążyłam się dowiedzieć, jest ono jedno z najniższych w porównaniu z podobnymi placówkami w sąsiednich powiatach - nadmieniła również” GW 25.04.03).

Obydwa czasopisma zauważają także inicjatywy Zespołu Opieki Zdrowotnej w Wagrowcu, włączające się w ogólnopolskie akcje, jak np. „Biała sobota” czy „Dzień Honorowego Dawcy Krwi”. Sposób relacjonowania jest podobny i opiera się na cytatach pozytywnych wypowiedzi osób korzystających z takich akcji (, - «Biała sobota» to bardzo dobry pomysł - chwaliła B. Somerfeld. [...] - Życzymy więcej takich inicjatyw zgodnie stwierdzili H. Nowak i M. Nowicki” GW 18.10.02).

\section{Pomoc i opieka społeczna}

Zagadnienia dotyczące pomocy społecznej w obydwu tygodnikach ograniczają się do relacjonowania pracy wagrowieckiego Miejskiego Ośrodka Pomocy Społecznej oraz Powiatowego Ośrodka Pomocy Rodzinie. W omawianym okresie najczęściej przedstawiane były projekty obu 
ośrodków polegające na dożywianiu dzieci w szkołach podstawowych, pomoc dla najuboższych rodzin w przygotowaniu wyprawek szkolnych czy, jak w przypadku PCPR, pomocy w odnajdywaniu rodzin zastępczych i promowaniu adopcji. „Głos Wagrowiecki” ponadto zauważa i relacjonuje spotkania okolicznościowe pracowników obydwu ośrodków z władzami miasta i powiatu. Często stają się one w tym czasopiśmie punktem wyjścia do przedstawiania działalności obydwu ośrodków.

Teksty odnoszące się do tej problematyki publikowane w ,Tygodniku Wągrowieckim”, w odróżnieniu od „Głosu Wagrowieckiego”, zwykle są mocniej nacechowane emocjonalnie, często negatywnie, co można zauważyć już w tytułach (Wyprawki nie dotrq na czas? [tytuł] TW 30.08.02). Jednak nie krytykują one pracy samych ośrodków, których działalność oceniana jest pozytywnie, a odnoszą się do rozwiązań prawnych ograniczających możliwości tychże ośrodków (Skomplikowana procedura [śródtytuł] TW 30.08.02).

\section{Gospodarka komunalna i mieszkaniowa}

Artykuły związane z tą kategorią pojawiają się rzadko w obydwu czasopismach i w obydwu mają podobną postać. Najczęściej są to krótkie teksty o charakterze informacyjnym, pozbawione nacechowania jednoznacznie ujemnego bądź dodatniego. Dotyczą one działalności Urzędu Miasta w Wagrowcu w zakresie przyznawania dodatków mieszkaniowych oraz działalności Wagrowieckiego Towarzystwa Budownictwa Społecznego zarządzającego budynkami komunalnymi.

\section{Współpraca z zagranicą}

Problematyka ta w analizowanych czasopismach opiera się głównie na przedstawianiu kontaktów samorządu powiatowego, jak też samorządów gmin wchodzących w skład powiatu wagrowieckiego, z samorządami lokalnymi zagranicznych partnerów. Dominują tu kontakty z partnerami pochodzącymi z Unii Europejskiej (np. niemieckimi gminami Lüneburg i Adendorf w przypadku Wagrowca czy holenderskim De Bild a Mieściskiem). Jednak także zauważana jest współpraca z jednostkami samorządowymi pochodzącymi z obszaru Wspólnoty Niepodległych Państw, jak choćby podpisanie umowy partnerskiej pomiędzy rejonem Baranowi- 
cze (Białoruś) a Mieściskiem. Obydwa tygodniki nie ograniczają się do przedstawiania okolicznościowych spotkań samorządowców z partnerskich gmin. Równie często prezentowane są praktyczne dokonania i korzyści wynikające ze współpracy jednostek podlegających samorządom, głównie szkół („Do tej pory najwięcej korzyści ze współpracy wyniosła młodzież szkolna (swoją umowę ma z jedną z niemieckich szkół wągrowiecka „czwórka”). Uczniowie uczestniczą aktywnie w wymianie młodzieży, rozgrywają mecze i zawody sportowe między poszczególnymi szkołami i uczą się języków.” TW 23.05.03; „Dużo serca we współpracę z zagranicznymi partnerami wkłada także Gimnazjum Miejskie nr 1. Pod koniec ub. r. 14-osobowa grupa gimnazjalistów wyjechała do Krasnogorska w Rosji. Podczas międzynarodowego obozu gimnazjaliści nawiązali kontakty z rówieśnikami z Rosji, Litwy, Łotwy, a nawet Ukrainy” GW 06.06.03). W „Głosie Wagrowieckim” pojawiają się ponadto artykuły omawiające ważne wydarzenia w życiu społeczności lokalnych zagranicznych gmin partnerskich (,Sala posiedzeń ratusza była wypełniona do ostatniego miejsca podczas zaprzysiężenia JOACHIMA PRITZLAFFA (Socjaldemokratyczna Partia Niemiec) na burmistrza Adendorfu - partnerskiej gminy Wagrowca” [przedruk z „Der Adendorfer”] GW 07.02.03).

Działalność samorządów na polu współpracy z zagranicą w omawianym okresie nie ograniczała się tylko do nawiązywania i utrzymywania kontaktów z gminami partnerskimi w innych państwach. W związku ze zbliżającym się wówczas referendum akcesyjnym samorządy lokalne stały się inicjatorami spotkań informacyjnych na temat Unii Europejskiej oraz organizatorami proeuropejskich imprez ${ }^{9}$. Gminy ponadto tworzyły lokalne centra informacji europejskiej realizując rządowe plany kampanii informacyjnej na temat Unii Europejskiej. Wszystkie te działania samorządów znajdują one swe odbicie w relacjach pojawiających się na łamach obydwu tygodników. W przypadku „Głosu Wagrowieckiego” zamieszczane są one często w specjalnej kolumnie poświeconej tematyce unijnej (Euro Oko).

W sposobie prezentacji tej kategorii dominuje użycie słów i wyrażeń nacechowanych dodatnio, zarówno jeśli chodzi o kontakty z gminami unijnymi, jak i leżącymi na wschód od Polski. Brak jest tu wartościowania ujemnego mogącego osłabić pozytywne skojarzenia wśród czytelników.

9 Np. taką imprezą organizowaną przez władze samorządowe miasta Wagrowca są „majówki europejskie” organizowane w pierwszych dniach maja podczas tzw. „długiego weekendu”. 
Również dobór cytatów ilustrujących omawiane zagraniczne kontakty wydaje się być stronniczy. Prezentowane wypowiedzi są pozytywne lub, znacznie rzadziej, obojętne aksjologicznie, przypominające niejednokrotnie slogany i klisze językowe (,-- Wyjazd pozwolił mi poznać ich kulturę oraz umożliwił obcowanie z językiem - zauważa Natalia Nowicka, uczennica trzeciej klasy. Często więzi nawiązane z rówieśnikami podczas wymiany pielęgnowane są także później. - Mam wielu znajomych w Niemczech. Piszemy do siebie e-maile - podkreśla Karol Guździoł. Zyskałam wielu nowych przyjaciół w Niemczech. Melanie, którą wcześniej gościłam, w tym roku przyjedzie do mnie na wakacje - chwali się Lidia Wegner" GW 06.06.03). Podobny ton dominuje w przedstawianiu działalności samorządów w związku z akcesją Polski do Unii Europejskiej. W tekstach pojawiają się hiperbole i wyrażenia odwołujące się do patosu, nadające czasem efekt ironiczny, odwrotny od zamierzonego przez autora ("W wagrowieckiej Miejskiej Bibliotece Publicznej otwarto pierwszy w historii Jakubowego grodu ośrodek informacji europejskiej. [...] To historyczne wydarzenie dla miasta, na „dzień” przed wejściem Polski do UE, poprzedziło powstanie Szkolnych Klubów Europejskich we wszystkich prawie że szkołach, którym to między innymi ma służyć Miejski Ośrodek Informacji Europejskiej” GW 21.03.03). Wzmacnianiu pozytywnego efektu wśród czytelników służą także prezentowane na łamach analizowanej prasy lokalnej ,sondy" zawierające wyłącznie pozytywne wypowiedzi („Mówimy «TAK» Europie” GW 06.06.03), sugerujące odbiorcom prasy „niewłaściwość” ocen negatywnych. Jednak taki jednostronny sposób prezentacji mógł nie do końca przemawiać do czytelników i obniżać pewność przekazywanych treści ${ }^{10}$.

\section{Straż pożarna}

Zagadnienia obejmujące działalność Państwowej Straży Pożarnej w Wagrowcu i jednostek Ochotniczych Straży Pożarnych w pozostałych gminach zwykle połączone są z obchodami rocznic związanych z ich działalnością lub okolicznościowych spotkań z władzami gminnymi

10 Taki sposób prezentowania treści precyzyjnie ujmuje W. Pisarek, Nowa retoryka dziennikarska, Kraków 2002, s. 231: „Jawna stronniczość relacji obniża jej wiarygodność. Jeśli więc wiadomości nie mogą być całkowicie obiektywne, niechże chociaż wyglądają na obiektywne". 
(125 lat lania wody [tytuł] TW 23.05.03). Kolejnym wątkiem podejmowanym przez analizowaną prasę są problemy jednostek strażackich, kłopoty lokalowe, dotyczące insygniów (Maja nowy sztandar [tytuł] TW 27.06.03), a w szczególności wyposażenie remiz i jakość sprzętu, jakim dysponują. Zauważane i pozytywnie akcentowane są zwłaszcza dary i nieodpłatna pomoc udzielana jednostkom („Chwilę później na plac wjechał wóz bojowy: dar strażaków z zaprzyjaźnionej holenderskiej gminy Maartensdijk - De Bild. [...] W zamian za tak wspaniały prezent holenderscy strażacy zostali udekorowani specjalną odznaką, prezentującą kamień św. Wojciecha. W ten sposób zostali uznani za największych przyjaciół gminy Mieścisko" GW 13.09.02).

Działalność straży pożarnej, zarówno państwowej, jak i ochotniczej, oceniana jest pozytywnie. Natomiast pojawiająca się w tekstach krytyka adresowana jest do władz samorządowych, którym to podlegają jednostki OSP (,,Samochód był bowiem przygotowany do akcji, w zbiorniku była woda, do miejsca zdarzenia było niecałe $200 \mathrm{~m}$, ale ... brakowało kluczyków. - Jeżeli sołtys twierdzi, ze samochód nie powinien jechać do pożaru o 12.00, to co robił na miejscu zdarzenia po południu? - dziwi się pragnący zachować anonimowość druh z sarbskiej OSP. [...] Najwięcej ostrych słów kierowanych jest pod adresem sołtysa, któremu zarzuca się ukrycie kluczyków i przez to narażenie sąsiada na ogromne straty" GW 20.09.02).

\section{Problematyka wiejska}

Problematyka wiejska w obydwu tygodnikach związana jest ściśle z ogólnokrajowymi problemami rolnictwa. Pojawiają się więc tutaj, znane z prasy ogólnopolskiej, trudności i obawy związane z dostosowywaniem rolnictwa do standardów obowiązujących w Unii Europejskiej (Kłopoty z SAPARD-em [tytuł] GW 13.09.02; 9 tysięcy krów z kolczykami [tytuł] TW 17.01.03). Tematem dominującym w tej kategorii w pierwszych miesiącach 2003 roku stały się blokady dróg organizowane przez „Samoobronę". Inaczej jednak niż w prasie ogólnopolskiej, oceniane były one pozytywnie (Chca naszych głów! [tytuł] TW 28.03.03 - artykuł o karaniu uczestników blokad). Obok głównych tekstów pojawiają się również „sondy” zawierające wypowiedzi podkreślające stanowisko czasopisma, popierające protest rolników („Co Wągrowczanie sądzą o rolniczych blokadach?”: „Wydaje mi się, że mają rację!”, „Nie jestem rolnikiem, ale gorąco popieram protesty rolników”, „Rozumiem ich. Po prostu walczą 
o swoje”, „Generalnie popieram protesty rolników, bo jeżeli za kilogram żywca czy litr mleka rolnik dostaje tyle, że mu się nie opłaca produkować, to musi wyjść na ulice i protestować" GW 07.02.03).

Ponadto „Tygodnik Wagrowiecki” przedstawia prezentacje wiosek powiatu waggrowieckiego, koncentrując się na dokonaniach i osiagnięciach ich mieszkańców (Srebrna Góra - piękna wieś dziełem ich mieszkańców [tytuł] TW 30.08.02; Grylewo - przystanek do Gołańczy [tytuł] TW 20.09.02).

\section{Samorząd solecki i osiedlowy}

Sposób prezentacji samorządu sołeckiego jest podobny do sposobu przedstawiania organów samorządu terytorialnego. Relacjonowane są, mając często w „Głosie Wagrowieckim” charakter stenograficzny, spotkania sołtysów z burmistrzami (wójtami) gmin. W omawianym okresie upływały kadencje rad sołeckich (1998-2002), co także znalazło odbicie w treści artykułów. Na początku 2003 r. na łamach obydwu czasopism dominowały więc w tej kategorii wybory nowych sołtysów i rad sołeckich (Soltys z zaskoczenia [tytuł] GW 24.01.03; Nowi i starzy soltysi [tytuł] GW 07.02.03; Sottysi odchodza, sottysi przychodza [tytuł] TW 28.03.03).

W tekstach dotyczących samorządu sołeckiego brak jest zwykle silnego wartościowania, dodatniego bądź ujemnego i jednoznacznych ocen pracy urzędujących sołtysów. Pozytywnie natomiast oceniani są ustępujący sołtysi i rady sołeckie (,Niemal wszyscy ustępujący sołtysi zapisali chlubną kartę w działalności na rzecz mieszkańców gminy i swoich wsi. To za ich kadencji w tych miejscowościach pojawiły się telefony, wodociagi, drogi zostały pokryte asfaltem, wyremontowano świetlicę i remizy OSP, wymieniono oświetlenie na energooszczędne, a w czynie społecznym wykonano szereg prac, dzięki którym na wsi żyje się o wiele lepiej" TW 28.03.03). Jednoznaczne negatywne oceny pojawiają się tylko w stosunku do rządu i pracy Agencji Restrukturyzacji i Modernizacji Rolnictwa, których rozporządzenia wpływają bezpośrednio na pracę sołectw (,Sołtysi przypuścili atak na ARiMR: - Ta agencja jest w ogóle niepotrzebna i utrudnia nam normalną pracę - rzekł zbulwersowany Roman Witek z Pomarzanek" GW 24.01.03). W celu deprecjacji przeciwnika w tym sporze wykorzystywany jest przestarzały już epitet „miastowy”, który pojawia się w cytowanej wypowiedzi jednej z uczestniczek spotkania sołtysów z burmistrzem Skoków (,-- Minister Rolnictwa to chyba jest 
miastowy, bo robi z nas baranów - powiedziała sołtys Roszkówka" GW 24.01.03).

\section{Podsumowanie}

Poszczególne kategorie wchodzące w skład „samorządu terytorialnego" oceniane są w obydwu czasopismach podobnie. Zdecydowanie pozytywnie postrzegana jest współpraca $\mathrm{z}$ zagranica, zarówno kontakty z partnerskimi samorządami i wynikające stąd efekty, jak i przystąpienie Polski do Unii Europejskiej i możliwości wynikające dla społeczności lokalnej. W sposób korzystny oceniana jest również w obydwu czasopismach straż pożarna oraz problematyka wiejska. Źle natomiast określane są działania administracji rządowej, zwłaszcza wpływające na funkcjonowanie samorządów i jednostek im podległym. Nieco zaskakujące początkowo może się zaś wydawać jednoznaczne poparcie tygodników lokalnych dla rolniczych protestów i przeprowadzanych przez członków „Samoobrony” blokad dróg. Jednak po uwzględnieniu typowo rolniczego charakteru powiatu, staje się uzasadnione.

Pozbawione jednoznacznego wartościowania są artykuły dotyczące „ochrony środowiska”, ,pomocy i opieki społecznej” oraz „gospodarki komunalnej i mieszkaniowej”. Te elementy kategorii „samorząd terytorialny" pojawiają się również znacznie rzadziej na łamach obydwu czasopism. Mają one najczęściej postać krótkich tekstów, obojętnych aksjologicznie.

W obydwu tygodnikach w sposób negatywny przedstawiana jest działalność rad miejskiej (Wagrowiec) i powiatowej. Natomiast działalność burmistrza Wagrowca w „Głosie Wagrowieckim” oceniana jest pozytywnie w głównych tekstach, negatywnie zaś w komentarzach redakcyjnych. Ponadto uczestnictwo burmistrza w wydarzeniach nie związanych z pełnioną przez niego funkcją ma dla tego czasopisma charakter nobilitujący przedstawiane wydarzenie i jest wykorzystywane dla podkreślenia jego rangi. Inny jest również sposób prezentacji tej tematyki w obydwu czasopismach. „Głos Wagrowiecki” preferuje dokładne relacje z posiedzeń rad, zaś „Tygodnik Wagrowiecki” koncentruje się na ich głównych wątkach.

W różny sposób oceniana jest także postać dyrektora szpitala powiatowego. W „Tygodniku Wagrowieckim” charakteryzowany jest on negatywnie, a pojawiająca się krytyka ma charakter raczej personalny, natomiast w „Głosie Wagrowieckim” dla ocen jego działalności wykorzystywane są 
wyrażenia i słownictwo o konotacji pozytywnej, bądź mającej nasuwać pozytywne skojarzenia. W obydwu tygodnikach działalność samego szpitala i lokalnej służby zdrowia charakteryzowana jest w sposób dodatni, koncentrując się na poprawie wyposażenia szpitala i akcjach skierowanych do społeczności lokalnej.

Wpływ na taki sposób przedstawiania rzeczywistości ma również styl publikowanych tekstów oraz charakter pisma. Język publikacji „Tygodnika Wagrowieckiego" jest z reguły bardzo emocjonalny, silnie nacechowany. Również duża ilość zdjęć i ilustracji do tekstów oraz „krzyczące” tytuły, zwłaszcza na pierwszej stronie, mogą wskazywać na tabloidowy, chociaż w bardzo stonowanej formie, charakter tego czasopisma ${ }^{11}$. Natomiast artykuły publikowane w „Głosie Wagrowieckim” są zwykle słabiej nacechowane emocjonalnie, z wyjątkiem tych dotyczących organów władzy samorządowej. Rzadziej też można w nich odnaleźć wyrazy, zwroty i wyrażenia jednoznacznie pozytywne bądź negatywne, w tekstach zaś dominuje charakter informacyjny.

Podobnie jak w prasie ogólnopolskiej, występują tu więc tendencje (realizowane świadomie?) do zróżnicowania linii pisma w stosunku do pewnej grupy czytelników. Jednak, co odróżnia analizowane media lokalne, to mała różnorodność w doborze tematów i sposobie ich przedstawiania, zazwyczaj podobnym w obydwu czasopismach.

Przedstawiony w tej pracy sposób prezentacji tematyki samorządowej w prasie lokalnej dotyczy dwóch pism pochodzących z jednego powiatu, nie można więc generalizować otrzymanych wyników na całość mediów lokalnych. Zwłaszcza, że każde media lokalne są specyficzne, zazwyczaj silnie związane z lokalną społecznością i miejscem swego powstawania. Nie musi to jednak zmieniać faktu, że dobór tematów tej kategorii i metody ich przedstawiania czytelnikom, jak zaprezentowane powyżej, mogą być w tej grupie mediów podobne.

11 Por. np. „Pismo lekkie, niemęczące w lekturze. Jego formuła jest oparta na barwnej grafice, krzykliwych zdjęciach, plotkach towarzyskich i seksie. [...] Tabloidy są zawsze za prawem i porządkiem, przyjmują postawę: karać”, M. Janicki, Nowy „Fakt” prasowy, „Polityka” 2003, nr 43, s. 104 oraz „[Tabloid] Jest radykalny, ostry, jest vox populi w tym sensie, że stara się odgadywać nastroje społeczeństwa i w jego imieniu je artykułować”, T. Potkaj, Czytelnik ponad wszystko, ,Tygodnik Powszechny" 2003, nr 46, s. 3. 


\section{Summary}

The Author discusses the image of local government emerging from Polish local press, especially in those locations where several titles exist (and continue to operate). For the purpose of the paper two weeklies were selected and analyzed: „Głos Wagrowiecki" and „Tygodnik Wagrowiecki" which have the highest circulation and reach in the Wagrowiec area (powiat). The analysis is based on a sample covering all the issues between July 2002 and June 2003. 